\title{
$A b$ initio study of 1:1 complexes of nitrogen trifluoride with nitrous oxide and carbon dioxide in vacuo
}

\author{
ABDOLVAHAB SEIF ${ }^{\mathrm{a}, *}, \mathrm{R}_{\text {BAGHERZADEH }}^{\mathrm{b}}$, MOEIN GOODARZI $^{\mathrm{c}}$ and KHALED AZIZI ${ }^{\mathrm{a}}$ \\ ${ }^{a}$ Department of Chemistry, Faculty of Science, University of Kurdistan, Sanandaj, Iran \\ ${ }^{b}$ Department of Engineering, Aliabad Katoul Branch, Islamic Azad University, Aliabad Katoul, \\ Golestan, Iran \\ ${ }^{\mathrm{c}}$ Department of Chemistry, Institute for Advanced Studies in Basic Sciences (IASBS), Zanjan, Iran \\ e-mail: abdolvahabseif@gmail.com
}

MS received 25 February 2013; revised 29 May 2013; accepted 7 June 2013

\begin{abstract}
Quantum chemical calculations are carried out in order to investigate the heterodimers of $\mathrm{NF}_{3} \mathrm{with}$ isoelectronic and isostructure species of $\mathrm{N}_{2} \mathrm{O}$ and $\mathrm{CO}_{2}$ in gas phase within the MP2 (Møller-Plesset perturbation) and $\mathrm{CCSD}(\mathrm{T})$ levels. Three and four minima are located on the potential energy surfaces of $\mathrm{NF}_{3}-\mathrm{CO}_{2}$ and $\mathrm{NF}_{3}-\mathrm{N}_{2} \mathrm{O}$ systems at the MP2/aug-cc-PVDZ level, respectively. Single-point energy calculations at the MP2/aug-cc-PVTZ and CCSD(T)/aug-cc-PVDZ levels confirm results obtained at the MP2/aug-cc-PVDZ level show that atmospheric roles of $\mathrm{NF}_{3}-\mathrm{N}_{2} \mathrm{O}$ and $\mathrm{NF}_{3}-\mathrm{CO}_{2}$ systems are similar. The atom in molecules theory was applied to analyse the nature of intermolecular interactions. Also, natural bond orbital (NBO) analysis has been used in order to obtain charge transfer quota among heterodimers.
\end{abstract}

Keywords. Atmosphere; nitrogen trifluoride; carbon dioxide; nitrous oxide; atom in molecules (AIM).

\section{Introduction}

Non-covalent intermolecular interactions bridge the gap between free molecular systems and the corresponding condensed phases. The complexes formed by these noncovalent intermolecular interactions are significant per se. From a theoretical point of view, researchers have pointed out great interest in the investigation of their complexes. ${ }^{1-5}$

Investigation of non-covalent intermolecular interactions of $\mathrm{NF}_{3}$ with isoelectronic and isostructure species of $\mathrm{N}_{2} \mathrm{O}$ and $\mathrm{CO}_{2}$ should be very interesting because $\mathrm{NF}_{3}, \mathrm{~N}_{2} \mathrm{O}$ and $\mathrm{CO}_{2}$ species have important influences in the Earth's atmosphere.

Nitrogen trifluoride, $\mathrm{NF}_{3}$, is a man-made gas that once released into the atmosphere circulates from the surface to the stratosphere hundreds of times before it is destroyed by solar ultraviolet radiation. $\mathrm{NF}_{3}$ is nearly chemically inert in the atmosphere, but very effective in absorbing infrared radiation that the Earth emits. By trapping this infrared radiation, $\mathrm{NF}_{3}$ becomes a potent greenhouse gas. Also, it is one of the most extensively used per fluoro compounds (PFCs) in the semiconductor industry to etch and cut the silicon substrate for computer chips, and cleaning in plasma-enhanced chemical

*For correspondence vapour deposition (PECVD) processes. ${ }^{6-8} \mathrm{NF}_{3}$ is also used in hydrogen fluoride and deuterium fluoride lasers, which are types of chemical lasers. It is interesting that as an environmentally preferable compound substitute for sulphur hexafluoride or per fluorocarbons, $\mathrm{NF}_{3}$ is found to reduce the rate of damage in the atmosphere. ${ }^{9}$ With respect to more traditional fluorinated gases such as $\mathrm{CF}_{4}$ and $\mathrm{C}_{2} \mathrm{~F}_{6}, \mathrm{NF}_{3}$ offers advantages of avoiding carbon contamination residues, boosting productivity by greater than $30 \%$, and decreasing effluent emissions by $90 \% .{ }^{10,11}$ However, similar to other industrially important PFCs, ${ }^{12,13} \mathrm{NF}_{3}$ is a potential greenhouse gas, with an atmospheric lifetime of about 740 years. In terms of kilograms emitted, $\mathrm{NF}_{3}$ is about 17,200 times more effective as a greenhouse gas than carbon dioxide. ${ }^{14}$ High-volume applications such as DRAM computer memory production, the manufacturing of flat panel displays and large-scale production of thin-film solar cells in regions with insufficient ecological awareness continues to increase the emission of $\mathrm{NF}_{3} .{ }^{15,16}$

Recently, interactions between $\mathrm{NF}_{3}$ and different chemical species such as solid state, ionic and molecular form of materials have been studied both computationally and experimentally. In a thorough study, Antoniotti et al. ${ }^{17}$ analysed the nature of $\mathrm{NF}_{3}$ adsorption on solid surfaces. Their results revealed the first theoretical evidence for the behaviour of $\mathrm{NF}_{3}$ as a functional Lewis base when interacting with neutral Lewis 
acids. Furthermore, the complexes formed between $\mathrm{NF}_{3}$ with ionic $\left(\mathrm{M}^{+}, \mathrm{M}=\mathrm{H}, \mathrm{Li}, \mathrm{Na} \text { and } \mathrm{K}\right)^{18}$ and also neutral ambidentate electron donor species (HF, FCl, $\mathrm{HCN}$, and $\mathrm{HNC})^{19}$ have been analysed, computationally.

Nitrous oxide $\left(\mathrm{N}_{2} \mathrm{O}\right)$ is a harmful climate gas with tremendous global warming potential (GWP). When it compared to carbon dioxide $\left(\mathrm{CO}_{2}\right)$, as isoelectronic and isostructure species, $\mathrm{N}_{2} \mathrm{O}$ has 310 times the ability per molecule of gas to trap heat in the atmosphere. ${ }^{20}$ In addition to greenhouse influences, $\mathrm{N}_{2} \mathrm{O}$ can act as destructive factor of ozone layer. It is produced by both natural and human-related sources. It is also produced naturally from a wide variety of biological sources in soil and water, particularly microbial action in wet tropical forests.

To the best of our knowledge, there is no available information in the literature regarding either theoretical or experimental studies of the complexes containing non-covalent intermolecular interactions of $\mathrm{NF}_{3}$ with $\mathrm{CO}_{2}$ and $\mathrm{N}_{2} \mathrm{O}$. Thus, the present study reports a detailed examination of the stability of $\mathrm{NF}_{3}-\mathrm{CO}_{2}$ and $\mathrm{NF}_{3}-\mathrm{N}_{2} \mathrm{O}$ systems. This theoretical study provides valuable information on environmental problems such as greenhouse influences.

\section{Computational details}

All calculations have been performed with the Gaussian 03 quantum chemical package. ${ }^{21}$ Geometries of the isolated $\mathrm{NF}_{3}, \mathrm{CO}_{2}$ and $\mathrm{N}_{2} \mathrm{O}$ moieties and their heterodimers are fully optimized at the second-order Møller-Plesset perturbation method (MP2) ${ }^{22}$ in conjunction with the aug-cc-pVDZ basis set ${ }^{23}$ within the frozen core (FC) approximation on the singlet potential energy surface (PES). As shown in table 1, the optimized geometries of $\mathrm{NF}_{3},{ }^{24} \mathrm{CO}_{2}{ }^{25}$ and $\mathrm{N}_{2} \mathrm{O}^{26}$ at the MP2/aug-cc-pVDZ level are in good agreement with those of the experiment. To gain reliable relative energies of each heterodimer, single-point energy calculations at the MP2/aug-cc-pVTZ and CCSD(T)/augcc-pVDZ levels were carried out on the optimized geometries of MP2/aug-cc-pVDZ. Harmonic vibrational frequency calculations have been performed at the MP2/aug-cc-pVDZ level to confirm the nature of all heterodimers as local minima (with the number of imaginary frequencies NIMAG $=0$ ) and enable the evaluation of the zero-point vibrational energies (ZPEs). Stabilization energy of the heterodimers in the present study was calculated as the difference between the energy of the heterodimers and the sum of the energies of the isolated monomers in their minimum configuration. The counterpoise (CP) method ${ }^{27}$ has been used to take into account the basis set superposition error (BSSE) in the calculation of the energies and present the energies without any BSSEs. The atoms in molecules (AIM) methodology ${ }^{28}$ has been used with the AIM $2000^{29}$ programs to analyse the electron density in bond critical point of the systems considered at the MP2/aug-cc-pVDZ level. Finally, the natural bond orbital (NBO) technique was employed to investigate the charge transfer processes occurring at atomic charges using the NBO-3 program. ${ }^{30-32}$

\section{Results and discussion}

Nomenclature that has been used for the classification of different structures of the heterodimers is based on linear molecules that are used $\left(\mathrm{C}\right.$ for $\mathrm{CO}_{2}$ and $\mathrm{N}$ for $\mathrm{N}_{2} \mathrm{O}$ ) and the numbering of these heterodimers conforms to the ordering of the intermolecular interaction energy (corrected for ZPE and BSSE). The calculated binding energies for different heterodimers (without and with ZPE and BSSE corrections) in the MP2 and CCSD(T) levels are listed in table 2.

About the electronic characteristics of the solitary monomers, it is worth mentioning the presence of four minima in the molecular electrostatic potential (MEP) of the $\mathrm{NF}_{3}$ molecule and two minima for each $\mathrm{CO}_{2}$ and $\mathrm{N}_{2} \mathrm{O}$ species in figure 1. Regarding $\mathrm{NF}_{3}$, three of them are associated with lone pairs of F-atoms and one of them with a lone pair of nitrogen atoms. Also, in the $\mathrm{CO}_{2}\left(\mathrm{D}_{\infty \mathrm{h}}\right)$ and $\mathrm{N}_{2} \mathrm{O}\left(\mathrm{C}_{\infty \mathrm{v}}\right)$ molecules, two minima are located in the molecular plane. It is obvious that in the $\mathrm{N}_{2} \mathrm{O}$ molecule, more electronegativity of oxygen related to nitrogen $\left(\mathrm{O}_{3.5}>\mathrm{N}_{3.0}\right)$ is the factor behind shift of nonbonding electrons from nitrogen to oxygen. Positive

Table 1. Geometries of $\mathrm{NF}_{3}, \mathrm{CO}_{2}$ and $\mathrm{N}_{2} \mathrm{O}$ species at the MP2/aug-cc-pVDZ level and experimental (bond lengths in angstrom, bond angles in degree).

\begin{tabular}{llllll}
\hline Species & $\mathrm{N}-\mathrm{F}$ & $\mathrm{F}-\mathrm{N}-\mathrm{F}$ & $\mathrm{C}-\mathrm{O}$ & $\mathrm{N}-\mathrm{N}$ & $\mathrm{N}-\mathrm{O}$ \\
\hline $\mathrm{NF}_{3}$ & 1.385 & 101.6 & & & \\
$\mathrm{CO}_{2}$ & & & 1.180 & 1.174 & 1.190 \\
$\mathrm{~N}_{2} \mathrm{O}$ & $1.371^{21}$ & $102.2^{21}$ & $1.163^{22}$ & $1.126^{23}$ & $1.186^{23}$ \\
Experimental & & & & \\
\hline
\end{tabular}


Table 2. Stabilization energies $(\mathrm{kJ} / \mathrm{mol})$ of $\mathrm{NF}_{3}-\mathrm{CO}_{2}$ and $\mathrm{NF}_{3}-\mathrm{N}_{2} \mathrm{O}$ systems at the MP2 and CCSD(T) levels.

\begin{tabular}{|c|c|c|c|c|c|c|c|}
\hline \multirow[b]{2}{*}{ Heterodimers } & \multicolumn{3}{|c|}{ MP2/aug-cc-pVDZ } & \multicolumn{2}{|c|}{$\begin{array}{l}\text { MP2/aug-cc-pVTZ// } \\
\text { MP2/aug-cc-pVDZ }\end{array}$} & \multicolumn{2}{|c|}{$\begin{array}{c}\mathrm{CCSD}(\mathrm{T}) / \mathrm{aug}-\mathrm{cc}-\mathrm{pVDZ} / / \\
\mathrm{MP} / \text { aug-cc-pVDZ }\end{array}$} \\
\hline & $\mathrm{E}_{\mathrm{I}}$ & $\mathrm{E}_{\mathrm{I}}+\mathrm{BSSE}$ & $\mathrm{E}_{\mathrm{I}}+\mathrm{BSSE}+\mathrm{ZPE}$ & $\mathrm{E}_{\mathrm{I}}$ & $\mathrm{E}_{\mathrm{I}}+\mathrm{BSSE}$ & $\mathrm{E}_{\mathrm{I}}$ & $\mathrm{E}_{\mathrm{I}}+\mathrm{BSSE}$ \\
\hline $\mathrm{C} 1$ & -6.67 & -2.88 & -1.66 & -5.40 & -3.56 & -7.38 & -5.67 \\
\hline $\mathrm{C} 2$ & -6.14 & -2.70 & -1.58 & -5.13 & -3.49 & -6.90 & -5.30 \\
\hline C3 & -6.26 & -2.67 & -1.56 & -5.30 & -3.50 & -7.11 & -5.11 \\
\hline N1 & -6.71 & -3.38 & -2.20 & -6.27 & -4.24 & -7.15 & -6.30 \\
\hline N2 & -7.21 & -3.42 & -2.09 & -6.31 & -4.12 & -7.60 & -5.95 \\
\hline N3 & -6.80 & -2.79 & -1.60 & -5.17 & -3.21 & -6.31 & -5.50 \\
\hline N4 & -4.00 & -1.35 & -0.59 & -3.34 & -1.88 & -4.12 & -2.01 \\
\hline
\end{tabular}

values of the MEP are out of the plane and around the central atoms (carbon and nitrogen).

Molecular graphs (including the critical points and bond paths) and AIM parameters of of all heterodimers were reported in figure 2 and table 3 , respectively. Results of NBO methodology are provided in table 4. Finally, the ranking of all heterodimers in terms of binding energies and some exponential relationships were shown in figures 3 and 4 , respectively.

\subsection{Structural details of $\mathrm{NF}_{3}-\mathrm{CO}_{2}$ heterodimers}

Association of $\mathrm{NF}_{3}$ with $\mathrm{CO}_{2}$ monomer leads to the formation of three minima, $\mathrm{C} 1, \mathrm{C} 2$ and $\mathrm{C} 3$, on the singlet PES. Binding energies of the $\mathrm{NF}_{3}-\mathrm{CO}_{2}$ heterodimers including ZPE and BSSE corrections lie in the range of $1.56-1.66 \mathrm{~kJ} / \mathrm{mol}$ at the MP2/aug-cc-pVDZ level.

$\mathrm{C} 1$ is the most stable heterodimer of the $\mathrm{NF}_{3}-\mathrm{CO}_{2}$ system with a binding energy $1.66 \mathrm{~kJ} / \mathrm{mol}$ after corrections with BSSE and ZPE at the MP2/aug-cc-pVDZ level. $\mathrm{C} 1$ heterodimer includes only one interaction between $\mathrm{NF}_{3}$ and $\mathrm{CO}_{2}$ monomers in which oxygen atom of $\mathrm{CO}_{2}$ approaches $\mathrm{F}$ atom of $\mathrm{NF}_{3}$ to create O...F interaction with length $3.091 \AA$. This is the shortest distance between the interacting atoms of $\mathrm{O}$ and $\mathrm{F}$ in the $\mathrm{NF}_{3}-\mathrm{CO}_{2}$ system.

In $\mathrm{C} 2$ heterodimer, one of oxygen atoms of $\mathrm{CO}_{2}$ has interactions with two F-atoms of $\mathrm{NF}_{3}$ monomer (O...F) with bond length $3.327 \AA$ at the MP2/aug-cc$\mathrm{pVDZ}$ level. Also, carbon atom of $\mathrm{CO}_{2}$ reacts with other F-atom of $\mathrm{NF}_{3}(\mathrm{C} . . \mathrm{F})$ with bond length of $2.976 \AA$.

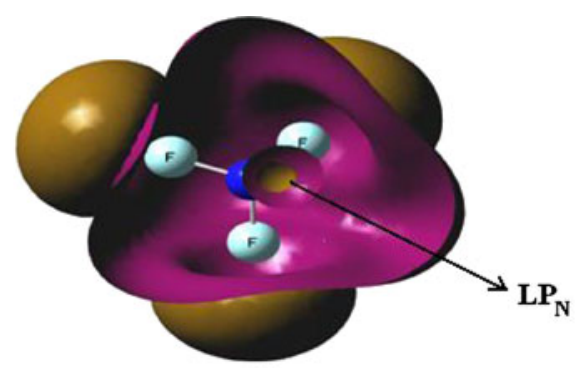

(a)

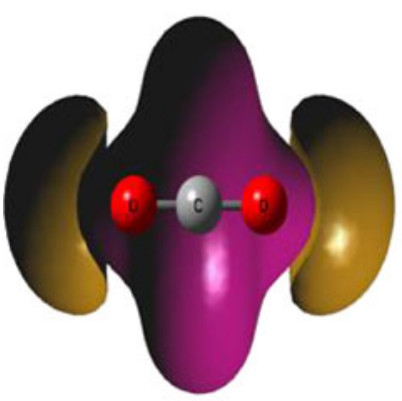

(b)

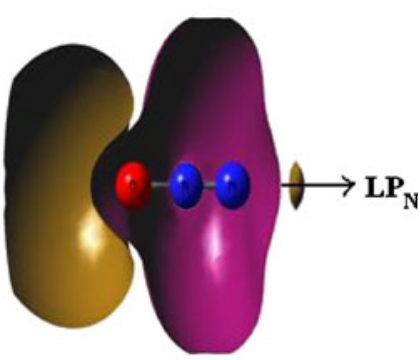

(c)

Figure 1. $\mathrm{MEP}$ of (a) $\mathrm{NF}_{3}$, (b) $\mathrm{CO}_{2}$ and (c) $\mathrm{N}_{2} \mathrm{O}$ at $\pm 0.004,0.020$ and 0.012 a.u. isosurfaces at the MP2/aug-cc-pVDZ level, respectively. The positive and negative regions of the MEP minima are indicated with violet and golden brown colours. 

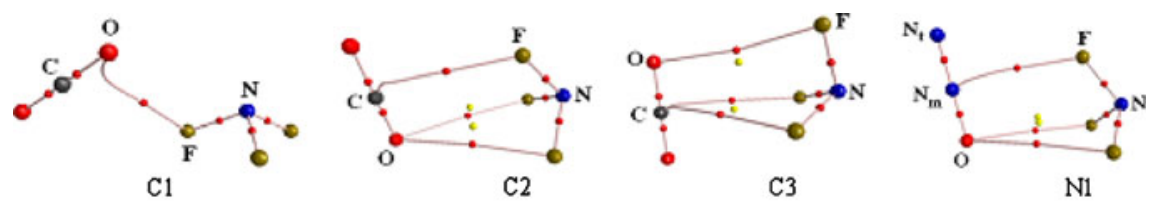

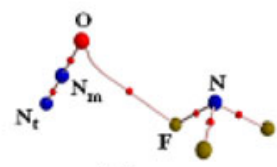

N2

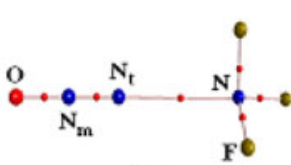

N3

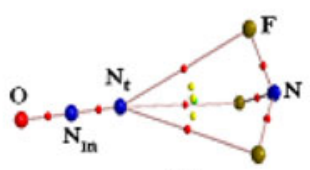

N4

Figure 2. Molecular graphs of all minima obtained at the MP2/aug-cc-pVDZ level (small circles among bonds represent ring critical point (RCP), small circles on bonds represent bond critical point (BCP)).

Binding energy of $\mathrm{C} 2$ heterodimer (corrected with BSSE and ZPE) is $1.58 \mathrm{~kJ} / \mathrm{mol}$ at the MP2/aug-ccpVDZ level.

C3 heterodimer is located as uppermost of local minimum in the $\mathrm{NF}_{3}-\mathrm{CO}_{2}$ system with binding energy of $1.56 \mathrm{~kJ} / \mathrm{mol}$. C3 heterodimer includes two interactions of C...F with bond lengths 3.085 and $3.098 \AA$, and one interaction of $\mathrm{O} \ldots \mathrm{F}$ with bond length $3.418 \AA$ at the MP2/aug-cc-pVDZ level. Note that the longest O...F and $\mathrm{C}$...F interactions belong to this heterodimer in the $\mathrm{NF}_{3}-\mathrm{CO}_{2}$ system. The long intermolecular distances of this heterodimer are in agreement with the interaction energy found.

\subsection{Structural details of $\mathrm{NF}_{3}-\mathrm{N}_{2} \mathrm{O}$ heterodimers}

Four minima have been found for the $\mathrm{NF}_{3}-\mathrm{N}_{2} \mathrm{O}$ system on the singlet PES. The binding energies of these heterodimers including BSSE and ZPE corrections lie in the range of $0.59-2.20 \mathrm{~kJ} / \mathrm{mol}$ at the MP2/aug-ccPVDZ level.

$\mathrm{N} 1$ is the most stable heterodimer of $\mathrm{NF}_{3}-\mathrm{N}_{2} \mathrm{O}$ system with binding energy of $2.20 \mathrm{~kJ} / \mathrm{mol}$ at the MP2/aug-cc-PVDZ level. $\mathrm{N}_{2} \mathrm{O}$ and $\mathrm{CO}_{2}$ are isoelectronic and isostructure monomers. Therefore, it should be interesting to compare the corresponding dimmers in $\mathrm{NF}_{3}-\mathrm{N}_{2} \mathrm{O}$ and $\mathrm{NF}_{3}-\mathrm{CO}_{2}$ systems. The corresponding heterodimer for $\mathrm{N} 1$ of $\mathrm{NF}_{3}-\mathrm{N}_{2} \mathrm{O}$ system is $\mathrm{C} 2$ of $\mathrm{NF}_{3}-$ $\mathrm{CO}_{2}$ system. Comparison of $\mathrm{N} 1$ and $\mathrm{C} 2$ heterodimers shows that both of them have two O...F interactions. Their main difference is the third interaction. In N1 heterodimer, middle nitrogen atom of $\mathrm{N}_{2} \mathrm{O}\left(\mathrm{N}_{\mathrm{m}}\right.$ stands for middle nitrogen atom of $\mathrm{N}_{2} \mathrm{O}$ ) reacts with F-atom of $\mathrm{NF}_{3}$ monomer $\left(\mathrm{N}_{\mathrm{m}} \ldots \mathrm{F}\right.$ interaction), while in $\mathrm{C} 2$ heterodimer, $\mathrm{C}$-atom of $\mathrm{CO}_{2}$ attacks F-atom of $\mathrm{NF}_{3}$ monomer. $\mathrm{N} 1$ heterodimer is merely $0.62 \mathrm{~kJ} / \mathrm{mol}$ more stable than $\mathrm{C} 2$ heterodimer. Also, the bond lengths of

Table 3. Interatomic distances $(\AA)$ and bond critical point data (a.u) calculated at the MP2/aug-cc-pVDZ level.

\begin{tabular}{lccccc}
\hline Heterodimers & Interaction & Interaction distance & $\rho$ & $\nabla^{2} \rho$ & $-\mathrm{G} / \mathrm{V}$ \\
\hline $\mathrm{C} 1$ & $\mathrm{O} \ldots \ldots \mathrm{F}$ & 3.091 & 0.0067 & 0.0334 & 1.2955 \\
$\mathrm{C} 2$ & $\mathrm{C} \ldots \ldots \mathrm{F}$ & 2.976 & 0.0059 & 0.0317 & 1.3964 \\
& $\mathrm{O} \ldots \ldots \mathrm{F}$ & 3.327 & 0.0030 & 0.0159 & 1.4309 \\
$\mathrm{C} 3$ & $\mathrm{O} \ldots \ldots \mathrm{F}$ & 3.327 & 0.0030 & 0.0159 & 1.4300 \\
& $\mathrm{O} \ldots \ldots \mathrm{F}$ & 3.418 & 0.0024 & 0.0137 & 1.5624 \\
& $\mathrm{C} \ldots \ldots \mathrm{F}$ & 3.085 & 0.0046 & 0.0261 & 1.5265 \\
$\mathrm{~N} 1$ & $\mathrm{C} \ldots \ldots \mathrm{F}$ & 3.098 & 0.0045 & 0.0254 & 1.5444 \\
& $\mathrm{~N}_{\mathrm{m}} \ldots . \mathrm{F}$ & 2.943 & 0.0067 & 0.0304 & 1.1979 \\
& $\mathrm{O} \ldots \ldots \mathrm{F}$ & 3.259 & 0.0035 & 0.0184 & 1.3677 \\
$\mathrm{~N} 2$ & $\mathrm{O} \ldots \ldots \mathrm{F}$ & 3.236 & 0.0037 & 0.0191 & 1.3392 \\
$\mathrm{~N} 3$ & $\mathrm{O} \ldots . . \mathrm{F}$ & 3.014 & 0.0074 & 0.0348 & 1.1631 \\
$\mathrm{~N} 4$ & $\mathrm{~N}_{\mathrm{t}} \ldots \ldots \mathrm{N}$ & 3.029 & 0.0065 & 0.0254 & 1.2525 \\
& $\mathrm{~N}_{\mathrm{t}} \ldots \ldots \mathrm{F}$ & 3.306 & 0.0033 & 0.0156 & 1.4051 \\
& $\mathrm{~N}_{\mathrm{t}} \ldots . . \mathrm{F}$ & 3.309 & 0.0033 & 0.0156 & 1.4071 \\
& $\mathrm{~N}_{\mathrm{t}} \ldots . . \mathrm{F}$ & 3.315 & 0.0032 & 0.0154 & 1.4109 \\
\hline
\end{tabular}

Symbols $\mathrm{N}_{\mathrm{t}}$ and $\mathrm{N}_{\mathrm{m}}$ stand for terminal and middle nitrogen atoms of $\mathrm{N}_{2} \mathrm{O}$, respectively. 
Table 4. Charge transfer (e) and dipole momentum (Debye) calculated at the MP2/aug-cc-pVDZ level within $\mathrm{NF}_{3}-\mathrm{CO}_{2}$ and $\mathrm{NF}_{3}-\mathrm{N}_{2} \mathrm{O}$ systems.

\begin{tabular}{llccc}
\hline Heterodimers & & $\mathrm{CT}$ & Total CT & Dipole momentum \\
\hline $\mathrm{C} 1$ & $\mathrm{CO}_{2} \rightarrow \mathrm{NF}_{3}$ & 0.0003 & 0.0005 & 0.4529 \\
$\mathrm{C} 2$ & $\mathrm{NF}_{3} \rightarrow \mathrm{CO}_{2}$ & 0.0008 & 0.0008 & 0.5511 \\
$\mathrm{CO} 3$ & 0.0000 & & \\
$\mathrm{C} 3$ & $\mathrm{NF}_{3} \rightarrow \mathrm{NO}_{3}$ & 0.0008 & 0.0010 & 0.5814 \\
$\mathrm{~N} 1$ & $\mathrm{CO}_{2} \rightarrow \mathrm{NF}_{3}$ & 0.0000 & 0.0002 & 0.6192 \\
& $\mathrm{NF}_{3} \rightarrow \mathrm{CO}_{2}$ & 0.0010 & & 0.3892 \\
$\mathrm{~N} 2$ & $\mathrm{~N}_{2} \mathrm{O} \rightarrow \mathrm{NF}_{3}$ & 0.0000 & -0.0002 & 0.3716 \\
& $\mathrm{NF}_{3} \rightarrow \mathrm{N}_{2} \mathrm{O}$ & 0.0002 & 0.0000 & \\
$\mathrm{~N} 3$ & $\mathrm{~N}_{2} \mathrm{O} \rightarrow \mathrm{NF}_{3}$ & 0.0006 & & 0.9464 \\
& $\mathrm{NF}_{3} \rightarrow \mathrm{N}_{2} \mathrm{O}$ & 0.0004 & 0.0000 & \\
$\mathrm{~N} 4$ & $\mathrm{~N}_{2} \mathrm{O} \rightarrow \mathrm{NF}_{3}$ & 0.0000 & & \\
& $\mathrm{NF}_{3} \rightarrow \mathrm{N}_{2} \mathrm{O}$ & 0.0000 & 0.0000 & \\
\hline
\end{tabular}

The symbol CT stands for charge transfer

$\mathrm{O} \ldots \mathrm{F}$ and $\mathrm{N}_{\mathrm{m}} \ldots \mathrm{F}$ in $\mathrm{N} 1$ heterodimer are shorter than those of $\mathrm{O} \ldots \mathrm{F}$ and $\mathrm{C} \ldots \mathrm{F}$ in $\mathrm{C} 2$ heterodimer, respectively. It is necessary to say that $\mathrm{N}_{\mathrm{m}} \ldots \mathrm{F}$ interaction is merely found in $\mathrm{N} 1$ heterodimer.

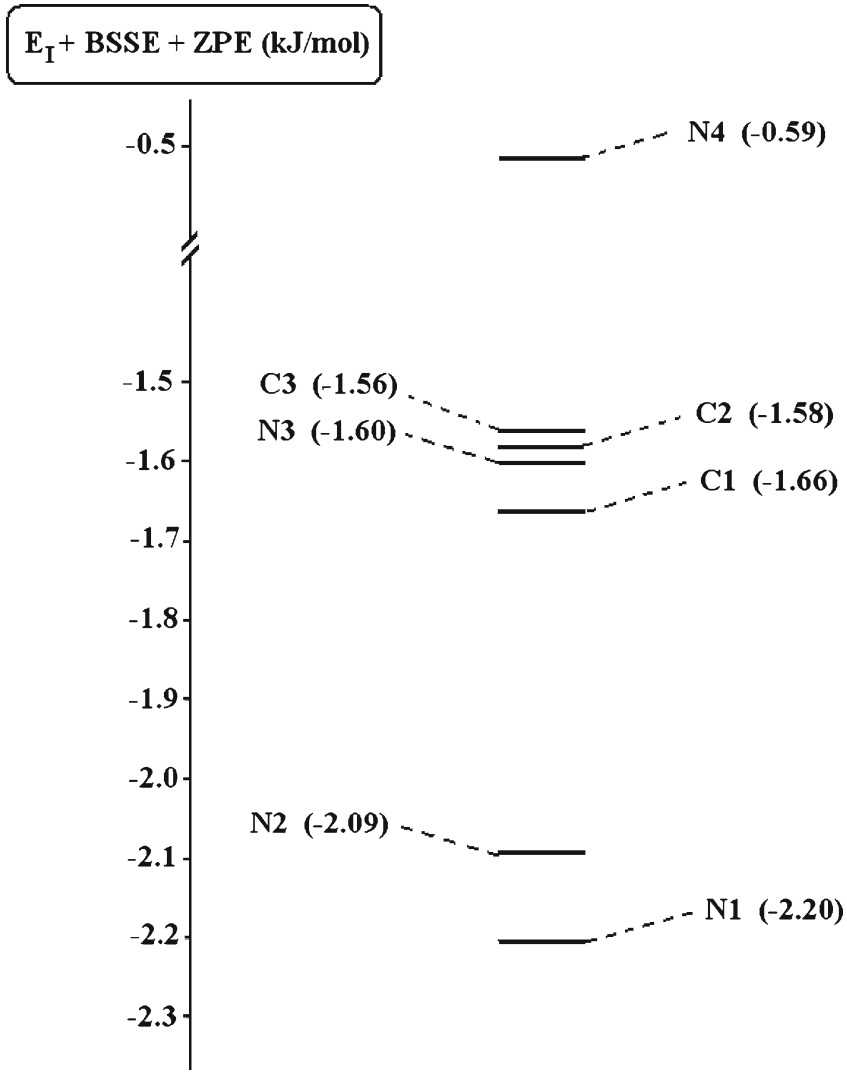

Figure 3. Ranking of all heterodimers obtained in both $\mathrm{NF}_{3}-\mathrm{N}_{2} \mathrm{O}$ and $\mathrm{NF}_{3}-\mathrm{CO}_{2}$ systems in terms of $\mathrm{E}_{\mathrm{I}}+\mathrm{BSSE}+$ $\mathrm{ZPE}$ at the MP2/aug-cc-pVDZ level.
$\mathrm{N} 2$ is the second stable heterodimer of $\mathrm{NF}_{3}-\mathrm{N}_{2} \mathrm{O}$ system. Binding energy of this heterodimer $(2.10 \mathrm{~kJ} / \mathrm{mol})$ is slightly lower than N1 heterodimer at the MP2/augcc-pVDZ level. Note that corresponding heterodimer for $\mathrm{N} 2$ of $\mathrm{NF}_{3}-\mathrm{N}_{2} \mathrm{O}$ system is $\mathrm{C} 1$ of $\mathrm{NF}_{3}-\mathrm{CO}_{2}$ system.
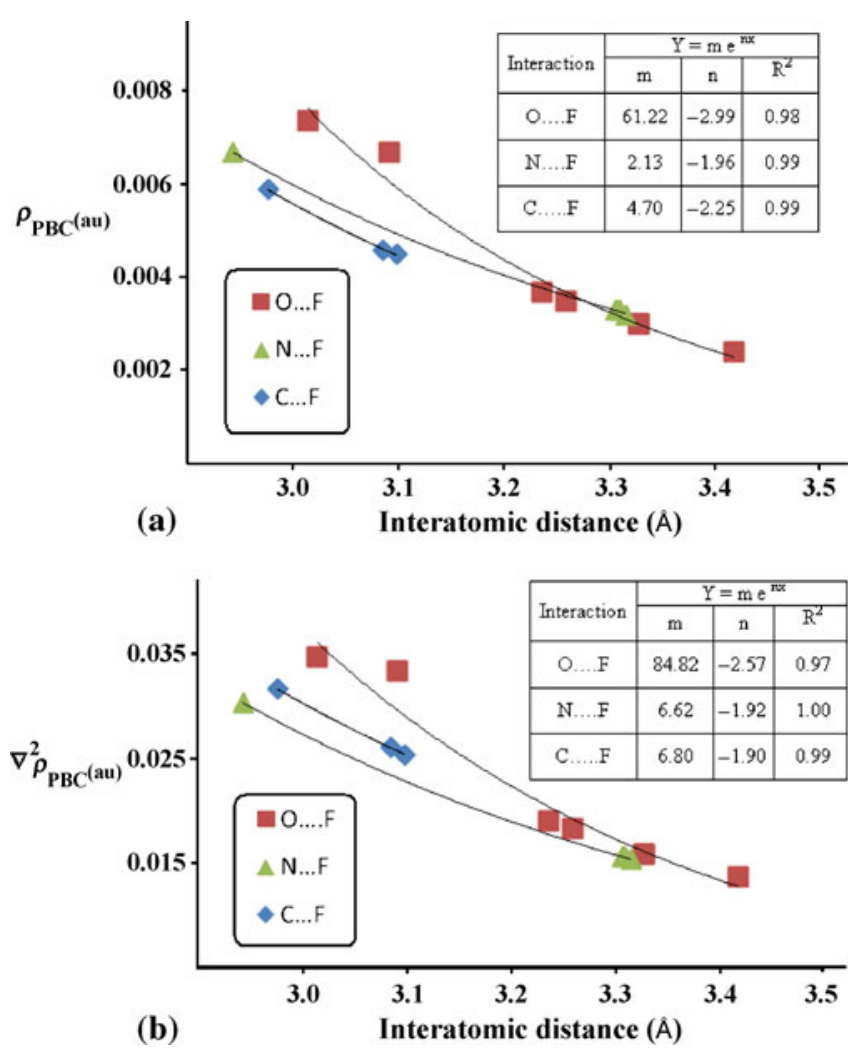

Figure 4. Exponential relationships between interatomic distances $(\AA)$ and the $\rho_{\mathrm{BCP}}(\mathbf{a}), \nabla^{2} \rho_{\mathrm{BCP}}(\mathbf{b})$. 
Both of them have only one interaction of O...F. Interaction distance of $\mathrm{O}-\mathrm{F}$ in $\mathrm{N} 2$ heterodimer $(3.014 \AA)$ is shorter than that of $\mathrm{C} 1$ heterodimer (3.094 $\AA$ ). This result is in agreement with more binding energy of $\mathrm{N} 2$ heterodimer with respect to $\mathrm{C} 1$ heterodimer.

In $\mathrm{N} 3$ heterodimer, lone pair of $\mathrm{N}$ atom of $\mathrm{NF}_{3}$ monomer attacks terminal nitrogen atom of $\mathrm{N}_{2} \mathrm{O}$ (denoted as $\mathrm{N} \ldots \mathrm{N}_{\mathrm{t}}$ ) to form interaction $\mathrm{N} \ldots \mathrm{N}_{\mathrm{t}}$ with bond length $3.029 \AA$. Note that $\mathrm{N}$... $\mathrm{N}_{\mathrm{t}}$ interaction is observed only in $\mathrm{N} 3$ heterodimer of $\mathrm{NF}_{3}-\mathrm{N}_{2} \mathrm{O}$ system. Binding energy of this heterodimer is $1.60 \mathrm{~kJ} / \mathrm{mol}$ at the MP2/aug-cc-pVDZ level.

$\mathrm{N} 4$ heterodimer is the least stable heterodimer among all heterodimers obtained in $\mathrm{NF}_{3}-\mathrm{N}_{2} \mathrm{O}$ and $\mathrm{NF}_{3}-$ $\mathrm{CO}_{2}$ systems. This heterodimer is formed when three F-atoms of $\mathrm{NF}_{3}$ approaches terminal $\mathrm{N}$-atom of $\mathrm{N}_{2} \mathrm{O}$ monomer to produce three $\mathrm{N}_{\mathrm{t}} \ldots \mathrm{F}$ interactions with different bond lengths of 3.306, 3.309 and $3.3015 \AA$. Results indicate that $\mathrm{N}_{\mathrm{t}} \ldots \mathrm{F}$ interaction exists only in this heterodimer. As shown in table 2, binding energy of N4 is $0.59 \mathrm{~kJ} / \mathrm{mol}$ at the MP2/aug-cc-pVDZ level.

In order to evaluate the binding energy (corrected with BSSE and ZPE) of heterodimers obtained in both $\mathrm{NF}_{3}-\mathrm{N}_{2} \mathrm{O}$ and $\mathrm{NF}_{3}-\mathrm{CO}_{2}$ systems, these energies are ranked in figure 3 as $\mathrm{N} 1>\mathrm{N} 2>\mathrm{C} 1>\mathrm{N} 3>\mathrm{C} 2>$ $\mathrm{C} 3>\mathrm{N} 4$. It can be seen that the two most dominant heterodimers in terms of binding energy belong to $\mathrm{NF}_{3}-$ $\mathrm{N}_{2} \mathrm{O}$ system, $\mathrm{N} 1$ and $\mathrm{N} 2$. The $\mathrm{C} 1$ heterodimer is in the third order. Although, this result acts as deriving force to say that $\mathrm{NF}_{3}-\mathrm{N}_{2} \mathrm{O}$ system plays a more important role than $\mathrm{NF}_{3}-\mathrm{CO}_{2}$ in the atmosphere, energy difference of $\mathrm{N} 1$ and $\mathrm{C} 1$ heterodimers is only $0.54 \mathrm{~kJ} / \mathrm{mol}$ at the MP2/aug-cc-pVDZ level. Therefore, it is reasonable to say that atmospheric roles of $\mathrm{NF}_{3}-\mathrm{N}_{2} \mathrm{O}$ and $\mathrm{NF}_{3}-\mathrm{CO}_{2}$ systems are similar. Note that this result is merely obtained with the investigation of binding energies. Therefore, other factors such as the atmospheric concentrations of $\mathrm{N}_{2} \mathrm{O}$ and $\mathrm{CO}_{2}$ species and their reaction with atmosphere molecules may influence this result.

Our results show that energy gaps and binding energies (corrected with BSSE and ZPE) of all heterodimers obtained at the MP2/aug-cc-pVDZ level are in low level of values (weak interaction). Therefore, the calculations of single-point energy have been carried out at the MP2/aug-cc-pVTZ and CCSD(T)/augcc-pVDZ levels on the optimized geometries of the MP2/aug-cc-pVDZ level. As shown in table 2, ranking of heterodimers at the MP2/aug-cc-pVTZ and CCSD(T)/aug-cc-pVDZ levels is similar to that of the MP2/aug-cc-pVDZ level. However, the energy gaps and binding energies (corrected with BSSE) of all heterodimers at the MP2/aug-cc-pVTZ and
CCSD(T)/aug-cc-pVDZ levels are bigger than those of the MP2/aug-cc-pVDZ level. Therefore, the results obtained from the calculations of single-point energy are in good agreement with those of MP2/aug-ccpVDZ level.

\subsection{AIM and NBO analysis}

For high quantum bases, atom in molecule is one of the strong implements to analyse interactions. According to the topological analysis of electron density in the theory of AIM, $\rho$ is used to describe the strength of a bond. In general, larger the value of $\rho$, stronger the bond is. The $\nabla^{2} \rho$ describes the characteristic of the bond. When $\nabla^{2} \rho<0$, the bond is covalent; as $\nabla^{2} \rho>0$, the bond is ionic, hydrogen with van der Waals interaction. Here, $\nabla^{2} \rho=\lambda_{1}+\lambda_{2}+\lambda_{3}, \lambda_{i}$ is an eigenvalue of the Hessian matrix of $\rho$. Based on the number and sign of the eigenvalues, critical points are classified as bond critical point, $\mathrm{BCP}(3,-1)$, ring critical points $\operatorname{RCP}(3,+1)$, and cage critical points $\mathrm{CCP}(3,+3)$. If one of the three $\lambda_{i}$ of critical point is positive and the other two are negative, this critical point is called bond critical point with symbol BCP $(3,-1)$. Bond critical points are located along a maximum electron density trajectory that connects two atoms, known as bond path. In the ring critical point, one of the three $\lambda_{i}$ of critical point is negative and the other two are positive which is denoted by $\operatorname{RCP}(3,+1)$. Existence of RCP indicates a molecular ring structure. Finally, when all the three $\lambda_{i}$ are positive, we denote it by $\operatorname{CCP}(3,+3)$ and call it the cage critical point. Existence of CCP shows that the molecule includes cage structure. The $-G_{\mathrm{C}} / V_{\mathrm{C}}$ ratio, being $G_{\mathrm{C}}$ and $V_{\mathrm{C}}$ respectively, the kinetic and potential energy density at $\mathrm{BCP}$, was used to measure covalency in noncovalent intermolecular interactions. Values greater than 1 generally indicate an intermolecular interaction without covalent character while ratios smaller than 1 are indicators of the covalent nature of the interaction. ${ }^{33}$ Values of topological parameters $\left(\rho, \nabla^{2} \rho\right.$ and $\left.-G_{\mathrm{C}} / V_{\mathrm{C}}\right)$ for each intermolecular $\mathrm{BCP}$ in $\mathrm{NF}_{3}-\mathrm{CO}_{2}$ and $\mathrm{NF}_{3}-\mathrm{N}_{2} \mathrm{O}$ systems are given in table 3. Molecular graphs for all heterodimers are also shown in figure 2.

As shown in table 3, $\rho$ values are in the ranges 0.0024-0.0067 and 0.0032-0.0074 au within $\mathrm{NF}_{3}-\mathrm{CO}_{2}$ and $\mathrm{NF}_{3}-\mathrm{N}_{2} \mathrm{O}$ systems, respectively. Therefore, the range of $\rho$ values in $\mathrm{NF}_{3}-\mathrm{CO}_{2}$ system is very close to that of $\mathrm{NF}_{3}-\mathrm{N}_{2} \mathrm{O}$. It is interesting to know that the biggest $\rho$ values between interacting atoms of $\mathrm{NF}_{3}-$ $\mathrm{CO}_{2}$ and $\mathrm{NF}_{3}-\mathrm{N}_{2} \mathrm{O}$ systems belong to $\mathrm{O} \ldots \mathrm{F}$ interactions in $\mathrm{C} 1(0.0067 \mathrm{au})$ and N2 (0.0074 au). Both C1 and $\mathrm{N} 2$ heterodimers include only $\mathrm{O} \ldots \mathrm{F}$ interaction 
between intended monomers. The investigation of values obtained for $\nabla^{2} \rho$ in the $\mathrm{NF}_{3}-\mathrm{CO}_{2}$ and $\mathrm{NF}_{3}-\mathrm{N}_{2} \mathrm{O}$ systems show that all of them are small as well as positive and it should be within the following ranges: $0.0137-0.0334$ a.u. for $\mathrm{NF}_{3}-\mathrm{CO}_{2}$ system and 0.0154 0.0348 a.u. for $\mathrm{NF}_{3}-\mathrm{N}_{2} \mathrm{O}$ system. All values reported for $-G_{\mathrm{C}} / V_{\mathrm{C}}$ ratio of heterodimers in $\mathrm{NF}_{3}-\mathrm{CO}_{2}$ and $\mathrm{NF}_{3}-$ $\mathrm{N}_{2} \mathrm{O}$ systems are greater than 1 , as shown in table 3 . Therefore, the small electron density and positive values of $\nabla^{2} \rho$ with $-\mathrm{G}_{\mathrm{C}} / \mathrm{V}_{\mathrm{C}}>1$ indicate that all intermolecular interactions in the $\mathrm{NF}_{3}-\mathrm{CO}_{2}$ and $\mathrm{NF}_{3}-\mathrm{N}_{2} \mathrm{O}$ systems are weak interactions of noncovalent without any covalent characters. Exponential relationships can be obtained between the intermolecular distances and the values of $\rho_{\mathrm{BCP}}$ and $\nabla^{2} \rho_{\mathrm{BCP}}$ (figure 4). Thus, when the intermolecular distance of the interacting atoms decreases, the values of $\rho_{\mathrm{BCP}}$ and $\nabla^{2} \rho_{\mathrm{BCP}}$ increase. Values obtained for $R^{2}$ (as regression) quantity are greater than 0.97 supporting accuracy of our results in this project.

The NBO analysis is carried out to determine charge transfer quota in the $\mathrm{NF}_{3}-\mathrm{CO}_{2}$ and $\mathrm{NF}_{3}-\mathrm{N}_{2} \mathrm{O}$ systems. Table 4 shows that values of charge transfer between monomers as well as total charge transfer in the $\mathrm{NF}_{3}-$ $\mathrm{CO}_{2}$ and $\mathrm{NF}_{3}-\mathrm{N}_{2} \mathrm{O}$ systems are in the range of 0.0000 0.0010 e, except $\mathrm{N} 2$ heterodimer. In all heterodimers of $\mathrm{NF}_{3}-\mathrm{CO}_{2}$ system, $\mathrm{NF}_{3}$ monomer acts as electron main donor. In contrast, in $\mathrm{N} 2$ and $\mathrm{N} 1$ heterodimers of $\mathrm{NF}_{3}-$ $\mathrm{N}_{2} \mathrm{O}$ system, $\mathrm{NF}_{3}$ monomer acts as electron main donor and main acceptor, respectively. Note that N3 and N4 heterodimers include no charge transfers. It is quite interesting that results obtained from dipole momentum (0.37-0.95 Debye) of heterodimers indicate that there is a relationship between dipole momentum and binding energy in $\mathrm{NF}_{3}-\mathrm{CO}_{2}$ and $\mathrm{NF}_{3}-\mathrm{N}_{2} \mathrm{O}$ systems except $\mathrm{N} 4$ heterodimer. The relationship between dipole momentum and binding energy in $\mathrm{NF}_{3}-\mathrm{CO}_{2}$ and $\mathrm{NF}_{3}-\mathrm{N}_{2} \mathrm{O}$ systems are inverse and parallel, respectively (except for N4 heterodimer).

\section{Conclusion}

The data and discussion in the previous sections, lead us to the following major conclusions:

a) $\mathrm{NF}_{3}$ attack on $\mathrm{CO}_{2}$ monomer leads to formation of three minima, $\mathrm{C} 1, \mathrm{C} 2$ and $\mathrm{C} 5$. Their binding energies (corrected with BSSE and ZPE) are in the range of $1.56-1.66 \mathrm{~kJ} / \mathrm{mol}$ at the MP2/aug-ccpVDZ level.

b) $\mathrm{NF}_{3}$ attack on $\mathrm{N}_{2} \mathrm{O}$ monomer can produce four minima, N1, N2, N3 and N4, on PES. Binding energy range of these heterodimers (cor- rected with BSSE and ZPE) is between 0.59 and $2.20 \mathrm{~kJ} / \mathrm{mol}$ at the MP2/aug-cc-pVDZ level.

c) Based on the binding energies obtained at the MP2/aug-cc-pVDZ level (corrected with BSSE and ZPE), heterodimers can organize in the order $\mathrm{N} 1>\mathrm{N} 2>\mathrm{C} 1>\mathrm{N} 3>\mathrm{C} 2>\mathrm{C} 3>\mathrm{N} 4$. Although, the two most stable dimmers, $\mathrm{N} 1$ and $\mathrm{N} 2$, belong to the $\mathrm{NF}_{3}-\mathrm{N}_{2} \mathrm{O}$ system, energy difference between $\mathrm{N} 1$ and $\mathrm{C} 1$ heterodimers is only $0.54 \mathrm{~kJ} / \mathrm{mol}$ at the MP2/aug-cc-pVDZ level. Therefore, we cannot select $\mathrm{NF}_{3}-\mathrm{N}_{2} \mathrm{O}$ system as a dominant system. It is reasonable to say that atmospheric roles of $\mathrm{NF}_{3}-\mathrm{N}_{2} \mathrm{O}$ and $\mathrm{NF}_{3}-\mathrm{CO}_{2}$ systems are similar. Note that this result is merely obtained on the investigation of binding energies. Therefore, other factors such as atmospheric concentrations of $\mathrm{N}_{2} \mathrm{O}$ and $\mathrm{CO}_{2}$ species and their reaction with atmosphere molecules may influence this result.

d) $\mathrm{N} 1$ and $\mathrm{N} 2$ heterodimers of $\mathrm{NF}_{3}-\mathrm{N}_{2} \mathrm{O}$ system correspond to $\mathrm{C} 2$ and $\mathrm{C} 1$ heterodimers of $\mathrm{NF}_{3}-$ $\mathrm{CO}_{2}$ system, respectively. Both $\mathrm{N} 1$ and $\mathrm{N} 2$ heterodimers are more stable than $\mathrm{C} 2$ and $\mathrm{C} 1$ heterodimers.

e) Results obtained from the calculations of singlepoint energy at the MP2/aug-cc-pVTZ and $\mathrm{CCSD}(\mathrm{T}) / \mathrm{aug}-\mathrm{cc}-\mathrm{pVDZ}$ levels are in good agreement with those of MP2/aug-cc-pVDZ level.

f) In both $\mathrm{NF}_{3}-\mathrm{N}_{2} \mathrm{O}$ and $\mathrm{NF}_{3}-\mathrm{CO}_{2}$ systems, we have found all possible interactions between $\mathrm{F}$-atom of $\mathrm{NF}_{3}$ with $\mathrm{N}_{2} \mathrm{O}$ and $\mathrm{CO}_{2}$ molecules. In contrast, no interactions have been found between $\mathrm{N}$-atom of $\mathrm{NF}_{3}$ with $\mathrm{N}_{2} \mathrm{O}$ and $\mathrm{CO}_{2}$ molecules, expect $\mathrm{N} 3$ heterodimer.

g) Based on AIM analysis, the small electron density, positive values of $\nabla^{2} \rho$ and $-G_{\mathrm{C}} / V_{\mathrm{C}}>1$ indicate that all intermolecular interactions in $\mathrm{NF}_{3}-$ $\mathrm{N}_{2} \mathrm{O}$ and $\mathrm{NF}_{3}-\mathrm{CO}_{2}$ systems are weak interactions of noncovalent without any covalent characters.

h) Based on NBO analysis, the small values of charge transfer indicate a minor role in stability of dimers.

\section{References}

1. Alkorta I and Grabowski S J 2012 Comput. Theor. Chem. 9981

2. Seif A, Ebrahimi S, Vessally E and Goodarzi M 2013 Struct. Chem. DOI 10.1007/s11224-013-0218-0

3. Solimannejad M, Alkorta I and Elguero J 2007 Chem. Phys. Lett. 44923

4. Yang Y 2009 Int. J. Quantum Chem. 109266

5. Scheiner S 2009 J. Phys. Chem. B113 10421

6. Sinke G C 1967 J. Phys. Chem. 71359 
7. Oshinowo J, Riva A, Pittroff M, Schwarze T and Wieland R 2009 Solid State Technol. 5220

8. Ruff O, Fischer J and Luft F 1928 Zeitschrift für anorganische und allgemeine Chemie 172417

9. Reichardt H, Frenzel A and Schober K 2001 Microelectron. Eng. $\mathbf{5 6} 73$

10. Ishii F and Kita Y 2000 in Advanced inorganic fluorides (eds) T Nakajima, B ZZemva and A Tressaud (Amsterdam: Elsevier) Chapter 19, p. 629

11. Meshri D T 2000 in Advanced inorganic fluorides (eds) $\mathrm{T}$ Nakajima, B ZZemva and A Tressaud (Amsterdam: Elsevier) Chapter 20, p. 673

12. Finlayson-Pitts B J and Pitts J N 2000 Chemistry of the upper and lower atmosphere (San Diego: Academic Press)

13. Brasseur G P, Jorlando J J and Tyndall G S (eds) 1999 Atmospheric chemistry and global change (New York: Oxford University Press)

14. Robson J I, Gohar L K, Hurley M D, Shine K and Wallington T 2006 Geophys. Res. Lett. 3310817

15. Prather M J and Hsu J 2008 Geophys. Res. Lett. 35 12810

16. Tsai W T 2008 J. Hazard. Mater. 159257

17. Antoniotti P, Borocci S and Grandinetti F 2004 Eur. J. Inorg. Chem. 20041125

18. Peia K, Lianga J and Lia H 2004 J. Mol. Struct. 690159

19. Blanco F, Alkorta I, Rozas I, Solimannejad M and Elguero J 2010 Phys. Chem. Chem. Phys. 13674

20. Sloss L L 1992 Nitrogen oxides control technology fact book. Noyes Data Corporation, p. 6. ISBN 978-0-81551294-3

21. Frisch M J, Trucks G W, Schlegel H B, Scuseria G E, Robb M A, Cheeseman J R, Montgomery J A Jr, Vreven T, Kudin K N, Burant J C, Millam J M, Iyengar S S, Tomasi J, Barone V, Mennucci B, Cossi M, Scalmani G, Rega N, Petersson G A, Nakatsuji H, Hada M, Ehara M, Toyota K, Fukuda R, Hasegawa J, Ishida M, Nakajima
T, Honda Y, Kitao O, Nakai H, Klene M, Li X, Knox J E, Hratchian H P, Cross J B, Adamo C, Jaramillo J, Gomperts R, Stratmann R E, Yazyev O, Austin A J, Cammi R, Pomelli C, Ochterski J W, Ayala P Y, Morokuma K, Voth G A, Salvador P, Dannenberg J J, Zakrzewski V G, Dapprich S, Daniels A D, Strain M C, Farkas O, Malick D K, Rabuck A D, Raghavachari K, Foresman J B, Ortiz J V, Cui Q, Baboul A G, Clifford S, Cioslowski J, Stefanov B B, Liu G, Liashenko A, Piskorz P, Komaromi I, Martin R L, Fox D J, Keith T, Al-Laham M A, Peng C Y, Nanayakkara A, Challacombe M, Gill P M W, Johnson B, Chen W, Wong M W, Gonzalez C and Pople J A 2003 Gaussian 03 (Revision B 03) Gaussian Inc Pittsburgh

22. Møller C and Plesset M S 1934 Phys. Rev. 46618

23. Dunning T H, Peterson K A and Wilson A K 2001 J. Chem. Phys. 1149244

24. Sheridan J and Gordy W 1950 Phys. Rev. 79513

25. Greenwood N N and Earnshaw A 1997 Chemistry of the elements (2nd ed.) Butterworth-Heinemann, p. 1340. ISBN 0080379419

26. Teffo J T and Chedin A 1989 J. Mol. Spectrosc. 135389

27. Boys S F and Bernardi F 1970 Mol. Phys. 19553

28. Bader R F W 1990 in The international series of monographs of chemistry (eds) J Halpen and M L H Green (Oxford: Clarendon Press)

29. Biegler-Konig F and Schonbohm J 2002 AIM2000 Program Package, Ver. 2.0. University of Applied Sciences, Bielefeld

30. Curtiss L, Pochatko D G, Reed A E and Weinhold F 1985 J. Chem. Phys. 822679

31. Reed A E and Weinhold F 1985 J. Chem. Phys. 831736

32. Foster J P and Weinhold F 1980 J. Am. Chem. Soc. 102 7211

33. Ziółkowski M, Grabowski S J and Leszczynski J 2006 J. Phys. Chem. A110 6514 